\title{
Being Accountable and Resultant Stakeholder Confidence in the Era of the Decolonisation of the University
}

\author{
Felix Omal ${ }^{1}$ \\ ${ }^{1}$ Ali Mazrui Centre for Higher Education Studies, School of Education, University of Johannesburg Johannesburg, \\ South Africa \\ Correspondence: Felix Omal, Ali Mazrui Centre for Higher Education Studies, School of Education, University of \\ Johannesburg, Johannesburg, South Africa.
}

Received: July 4, 2017

Accepted: October 9, 2017

Online Published: March 11, 2019

doi:10.5430/irhe.v4n1p24

URL: https://doi.org/10.5430/irhe.v4n1p24

\begin{abstract}
Today's higher education landscape can best be described as unpredictability. This places university governing councils in critical places to begin to think deeply in terms of forms positionality to provide effective governance. For instance, in the South African higher education scenario currently, there are urgent calls for university decolonisation as such university governing bodies have to show that they are on top of the game through demonstrating to their stakeholders that have in place a responsive habitus that supports stakeholder accountability and confidence in these times. This paper examines the relationship between stakeholder accountability and confidence in institutional values that underpin effective governance. Consequently, this paper was developed from a research project that looked at the role of the university councils in bringing about good governance in the former historically black South African universities grappling with such institutional realities. Utilizing the notion of micro-politics developed from the concept of cultures derived from a multi-theoretical approach, the paper examines the framing of good university governance by governing bodies. Data for this study was collected from institutional documentary sources in the public domain, interviews and surveys. This paper ends with suggestions of governance practices that would assist the university councils grappling with such institutional contexts to provide good governance and possibilities for further research.
\end{abstract}

Keywords: comprehensive universities, university councils, governance practice, institutional stakeholders

\section{Introduction}

The role of stakeholder governed university councils in the post-1994 South African higher education in the transformation and decolonisation of higher education remains contested. As a result, there remains debate and concern of what steps the university councils are doing to address the key issues that are underpinning the calls for rapid decolonisation and eventual transformation of the universities within their jurisdiction. In this light, the paper is examining the relationship between accountability practices of the university council as the major decision maker in the university and the resulting stakeholder confidence. The new changes in higher education and the inabilities of the university councils to adequately respond as expected has made affected stakeholders riotous.

Consequently, in the post-1994 South African higher education dispensation, higher education had to be transformed to meet the developmental needs of the nation. The key instrumentality and driver of change where the state policy of cooperative governance (Moja, \& Hayward, 2000). Under the notion of cooperative governance, the university governing bodies would be in charge of the university governance (CHE,2004a) and were expected to set accountable practices that meet the needs of its different stakeholders (Alderman \& Carey 2009a; Casper \& Henry 2001; Liefner 2003). The demands to bring about stringent accountability practices is due to pressing stakeholder demands as result of pressing increased changes in higher education landscape, contested reduced state funding, massification (Kezar, \& Eckel,2004; Cloete, \& Maassen, 2002; Burke \& Minassians, 2003).

In 2015 with increased university student protests across most South African universities for no university fees and the decolonisation of the university, university councils were in the spotlight. University councils under hot stakeholder pressures and turbulences that engulfed the universities to survive and prevent institutional ungovernability make hard choices between accountability and quality, accountability and equality, accountability and access. What is being given little diagnosis is that these contestations seem to anchor from the implementation of 
this state policy have been characterised by difficulty and different interpretation that has affected its success. According to the different independent assessor reports commissioned by the department of education the major causes of governance challenge confronting the university councils laid in the processes of implementation that led to alleged governance dysfunctionality and crises (Department of education reports; on University of the North, 1997; University of Transkei, 1998; University of Fort Hare, 1999).

However, I like to argue that two aspects are critical to this process. Stakeholder accountability and stakeholder confidence. The relationship between these two aspects is critical for effective governance. Good governance is closely related to how the university council is able to provide sufficient accountable frameworks to respond to different stakeholder needs and demands and ability to ensure the different stakeholders have confidence in the university council to provide effective governance as result of this process and practises. The outgrowth of these dynamic interactions was the present approach to institutional governance and management in higher education, which may be termed the "autonomy with accountability" model (Neave and Van Vught 1994). On the one hand, it seeks to provide institutions with the freedom and flexibility necessary to control their own fate as they are buffeted by the tides of change and the challenges of competition from home and abroad. The university governing institutions are expected to be good stewards of public funds, to provide quality education in return for public support, and produce graduates, research and services that are relevant to the needs of society and the economy. In short, governing institutions should be largely free to manage their own affairs - and be held accountable for their performance in doing so in pursuit of government policy objectives.

In the quest for appropriate checks and balances, higher education policymakers have sought to link increased management autonomy with greater management accountability for institutional performance in the use of public funds. For university governing boards, this has had several consequences (Fielden, 2008: 37-38). First, board members not drawn from the university community or from the government have been increased (or in some cases introduced) in the effort to strengthen accountability to employers for the quality of graduate preparation, and to graduates for employment prospects stemming from the relevance of their studies. Second, clear mandates have been given to boards for institutional strategic planning and for monitoring management's progress in achieving strategic goals (Marshall, 2009). Third, boards are being asked to ensure that institutional resources are used efficiently (Ogle et al, 2008). As one consequence, board membership appears progressively less likely to be based purely on formulas for the political inclusion of university interest groups and more likely to incorporate technical and professional skills related to financial planning, human resource management, and legal expertise (Sporn, 2002).

The data for the paper was collected from documentary sources available in the public media, interviews and surveys. The paper is structured in the following sections: The first part of the paper examines the challenges of stakeholder governed university councils across the post-1994 South African universities. The second part of the paper examines the conceptual framework, the methods used in data collection and analysis of the results of the paper. The third part of the paper provides the conceptualization of governance from the data. The last part of the paper ends a call for greater professionalization of the governance best practises for improving governance in strong stakeholder governed university councils and possible areas of further research and policy implications.

\subsection{The Challenges of Stakeholder Governed University Councils in the Post-1994 South African Universities}

Comprehensive universities are those higher education institutions that were formerly historically disadvantaged institutions that existed in the former homeland areas of South Africa by the creation of the apartheid state. However, by a series of different acts of the post-apartheid state, it was decided to convert these ailing institutions to comprehensive universities and some into universities of technology (DoE, 2004b). Comprehensive universities across the former different homeland areas now offer vocational and degree qualifications to the university students (CHE, 2000). However, these state inspired policy conversions and integrations did not address certain projected stakeholder expectations and dreams. Over the years these institutions have become institutional stakeholder battle grounds and proxies for stakeholders against those perceived as responsible for the 1994 stakeholder inexorable unfulfilled promises and expectations (DoE, 1997). As a result, the institutional governance bodies across these universities, the university council, senate and institutional forums are sandwiched between satisfying stakeholder expectations at constituency and institutional level.

The council for higher education (CHE) in 2004 in transformation mode laid out the responsibilities of the university council, senate and institutional forum in bringing about effective university governance. It stated that the university council is responsible for the university governance of the university. The university senate is responsible for the academic affairs of the university. The institutional forum is responsible for guiding of the university governing council on the University transformation process. This tripod governance system was supposed to work together but 
the university senate and institutional forum are to report to the university council to the different committees of the university council. However, the CHE did not specify to the different university councils how this tripod university governance alliance is expected to work together to bring about the different processes of institutional transformation from the university council level. The CHE expected the different university governing bodies in conjunction with the other governance bodies in the tripod alliance in the different university contexts to figure this out. In the post-1994 South Africa, this university governance process has been characterised by continuous conflicts and differences of different magnitudes at all levels of the university council, university senate, and institutional forums (DoE, 2004b).

In the post-1994 South African higher education scenario, university governing bodies inherited diverse forms of institutional governance challenges partly that could be characterised as structural, systemic and cultural institutional governance challenges with which university governing bodies have to grapple (CHE, 2004). These institutional governance challenges have a strong historical undertone that is emblematic of the higher education system of the nation of the South Africa that simply takes on new connotations. The consequences of this state of affairs can best understand under two aspects: firstly, the absence of a culture of stakeholder accountability and secondly absence of stakeholder confidence in the university governance processes.

\subsection{The Absence of a Culture of Stakeholder Accountability}

The key indicators for emerging and prevailing crisis of stakeholder accountability according to the reports from the Independent assessors described from the CHE from 1990 to 2012, point to the fragile stakeholder relationships (University of the North, 1997; University of Fort Hare, 1999; University of Transkei, 1998; University of Kwa Zulu-Natal, 2011). The independent assessors report present aspects of institutions whose university councils have not carried out their mandate effectively, and whose relationship with Vice-Chancellors and management had all but broken down. Instances are reported in which university councils have abdicated their responsibility for governing to powerful interest groups, or, in the case of one institution, to the Vice-Chancellor. Instances are reported of weak linkages between structures of governance, stakeholder groups were reportedly wielding influence inappropriately outside the bounds of properly-constructed Institutional Forums; this was either through co-option in terms of patronage, factionalism, or through inappropriate attempts to dominate the governance process and to marginalize Senates. The senate was more of a passive sea-anchor than a propeller of change, and by weakly developed sub-structures for effective delegation of responsibilities. These reports continue to present reports of large executive committees of councils that mirrored university councils, and therefore its parent problems. That only acted in emergencies and in regard to routine administrative matters, its primary function was as a clearing house for recommendations from the senate and other committees of council prior to their consideration by the full council. Lastly, cases of university councils not cooperating with their senior executive leaving the university councils with no practical ability to implement its policies (University of the North, 1997; University of Kwa Zulu-Natal, 2011). Reference is made to the struggles of other governance structures, such as institutional forums, in defining the roles they ought to play in deepening institutional transformation (Hall et al., 2002).

\subsection{Stakeholder Confidence}

A second challenge that confronted the university councils was the crisis of low confidence in the leadership styles and governance practices. The numerous reports of grappling with the formal mechanisms and procedures of governance had the negative effect on the stakeholder's trust in the leadership of these universities (Dept. of education reports University of Fort Hare, 1999). In addition, the crisis of no confidence that faced these institutions was due to the following stakeholder factors in the university governance processes: The limited participation of various stakeholders in policy discussions with councils. There are several reasons why this has been the case. For example, the reports outline instances of a fledgling system of delegated authorities, fledgling committee system, some councilors wanting to be involved in the day to day running of the institution, a lack of clear agendas for council meetings, control over a council's work being exercised by the secretary, council members' generally weak grasp of due processes at the level of formal governance, infrequent meetings of council and committees of council, slow and haphazard responses to issues and at times inappropriate action by various parties, failure of stakeholders to implement an agreed course of action (Dept. of education reports on University of Kwa Zulu-Natal, 2011). Instances of cronyism within university councils have been reported that led to a subversion of due processes as well as to corruption (Dept. of education report on University of the North, 1997; University of Kwa Zulu-Natal, 2011). Independent assessor reports on several universities have indicated instances of gross stakeholder meddling. These reports list clues of dominant interest stakeholder sacrileges in the blatant ignoring of many of a university's rules, selection processes and appointment of handpicked individuals to senior managerial positions (Habib, 2001:14). 
These individuals were empowered to bypass structures and ignore normal rules, processes and procedures required for transparent governance. The result was a collapse of important operational structures that stakeholders and that serve as checks and balances in the management of public institutions (Habib, 2001:14).

As such in conclusion, the manner in which cooperative governance was implemented across the stakeholder governed university councils led to gross challenges that led to the different institutional stakeholders doubting the legitimacy of the leadership and governance stakeholder university councils to be able to govern the universities. This crisis of governance confidence is responsible for less regard for the institutional values that underpin the leadership of these universities.

\section{The Conceptual Framework of the Study}

This paper uses the concept of culture as an organizing framework in a multi-theoretical approach to the framing of effective university governance practices by governing bodies within such institutional contexts. This paper makes use of this organizing concept within a unique form of a micro political framework developed on the work of the following writers: Blasé, (1998) on micro politics, Bourdieu (1996) on species of social capital, Foucault (1991) and his concept of "circuits of power" located within social critical sociological perspectives which foreground interests, power and power relations as mediators and sometimes drivers of human interactions (Cross \& Naidoo, 2011:518) in the era of the decolonisation of the university across the South African higher education.

Decoloniality is the thinking and practices from peoples and parts of the world that have experienced even the Enlightenment itself as a darkening of the world and have endured modernity as dehumanisation (Mbembe, 2001; Mignolo, 2008; Nabudere, 2011; Said, 1983). As such, de-coloniality as a philosophy of liberation entails the rehumanisation of the dehumanised and the courage to care and to love, to set afoot a new planetary human citizenship that Cesaire referred to as a universal experience of being that is enriched by the particular (Magubane,2007; Cesaire,1972). Decoloniality is, in other words, the philosophy of those that have been victims of slavish and colonial fundamentalism and resist the temptation to liberate themselves using the logic of the same fundamentalism (Freire, 1993; Maldonado-Torres, 2007).

For sake of this paper the attributes of effective university governance are drawn from the White Paper of 1997 on the goals of higher education transformation (CHE, 2004) and the is hunch is how the university council could work with different institutional stakeholder representatives to craft institutional governance responses as forms of effective governance that address these challenges within these institutional contexts. These organising concepts rooted in the conflict of social action as analytical tools are being used to make the following assumptions:

i) Drawing from Rousseau (1887) and his notion of a social contract, this paper argues that councils have unique governance pact between different stakeholders represented at the university council to create conditions at different levels of university council that support effective university governance in comprehensive higher education environments. ii) Drawing from Bourdieu (1996) and his notion of social capital, this paper argues that University councils are composed of individuals or groups with different forms of social capital (individual and collective assets) such as power, funds, public favour, influence and followership. These empowered constituencies have access to the various stakeholder networks through public-private partnerships that could be used to respond to the student accommodation crises that continue to confront the former historically black disadvantaged South African universities as forms and modes of practices that could constitute effective governance (Blasé,1998; Foucault,1991).

According to Steyn \& van Zyl, (2001:20), institutional culture is the "sum total" effects of the values, attitudes, styles of interaction, collective memories - the "way of life" of the university, known by those who work and study in the university environment, through their lived experience. Eckel (2003) suggest that culture shapes the governance process in profound ways and that cultural theory is important to understand governance. There are three domains of university governance cultures as knowledge bases that are prevalent in higher education leadership and governance literature; the bureaucratic, collegial, and political models (Baldridge et al, 1977). However, emerging research on higher education governance has generally been focused on four major analytical models: bureaucratic-rational, collegial, political, and garbage can or symbolic model (Baldridge et al., 1983). As such university councils exist at the interface of as knowledge domains to affect institutional governance practice. This depending on the level and dimension of micro-politics going on within the university councils at an institutional level, it will determine the type of governance culture as a model of governance practice the university council adopts to respond to the student accommodation crises as effective governance. 


\section{Methods of Data Collection and Analysis}

There are interactions between several stakeholders at different levels of governance within the university council is fundamental for improved governance practice. These practices reflect the different governance stakeholder's experiences, interpretations and perspectives. These understandings are often subjective stakeholder experiences informed by the stakeholder institutional governance constituencies' policies that cadre stakeholder members have to comply and work with as part of the stakeholder governance practice.

To be in the position to collect this kind of data involved using content analysis of institutional documents available in the public media, and interviews with the members of the university council. A total of 19 interviews were carried out by the members of the university council.11 internal members and 8 external members of the University from 20 external and 11 internal members of the university council. The data used for this paper was derived from the emerging themes from the content analysis of the documentary sources and interview protocols for members of the university council.

The study used a sequential exploratory mixed methods research paradigm (Creswell, Plano Clark et al., 2003) in the collection and analysis of the data in a case study (Yin, 2003) of one comprehensive university. The collection of data involved the use of document analysis (Payne \& Payne, 2004), face-to-face in-depth interviews (Corbetta, 2003; O'Leary, 2005) and surveys (Groves et al, 2004). The analysis of data utilized a thematic analysis approach (Bailey 1994:194). The first stage of survey data analysis after the data entry using SPSS format involved the use of descriptive statistics (Keith \& Punch, 2009). It involved the use of frequency distributions, means and standard deviations (variations). The next stage of the data analysis involved the use of correlations to explore if there are any relationships within the data. Using a Pearson moment correlation coefficient (Keith \& Punch, 2009), all the theme items on the survey instruments were correlated with each other in this process. The emphasis was to see if there are emerging relationships, the strengths of these relationships and what this means for models of effective governance.

A total of 331 usable survey forms were received from the students and staff from the university. The study had two separate survey instruments for the university students and the university members of staff. The survey included four major components (a) demographic information (b) University Council structures (c) University Council systems (d) university council cultures. On a 5-point Likert-type scales (Keith \& Punch, 2009) of [5 for very strongly agree; 4 for strongly agree; 3 for neutral / disagree or agree; 2 for strongly disagree; 1 for very strongly disagree] the participants were asked to indicate their perceptions of university council structures and processes as contributing to effective university governance on the item scales.

Table 1. Kinds of institutional stakeholders who participated in the interviews

\begin{tabular}{llll}
\hline Participants & Gender & Race & Stakeholder affiliation \\
\hline P1 & M & B & $\begin{array}{l}\text { Senior } \\
\text { management }\end{array}$ \\
P2 & Mniversity \\
P3 & B & SRC representative \\
P5 & M & B & Admin. employee \\
P6 & M & B & Academic employee \\
P7 & M & B & State representative \\
P8 & F & B & State representative \\
P9 & M & B & SRC \\
P10 & M & B & Senate representative \\
P11 & M & B & Legal resource person \\
P12 & M & B & State representative \\
P13 & M & B & State representative \\
P14 & M & B & Private sector \\
P15 & F & B & Private sector \\
P16 & F & B & Private sector \\
P17 & M & B & Admin. employee \\
& M & B & Senior \\
P18 & & & management \\
P19 & M & B & State representative \\
\hline & M & B & Traditional local leadership \\
\hline
\end{tabular}




\subsection{Fundamental Key Stakeholder Practices for Good Governance}

In the stakeholder governed university councils the following factors are fundamental to effective governance: the composition of the university council

\subsection{The Composition of the University Council}

The South African Higher Education Statue (1997, p26-27) stipulates that university councils have to be composed of a diversity of both internal and external stakeholders. The results of this study show that the university council is composed of different stakeholder representatives from different groupings within and outside the university. These stakeholder representations vary from institution to institution in the South African higher education landscape. The different stakeholder constituents have strong say on who represents them in the university council and its different committees.

Table 2. Kinds of stakeholder representations in the university council

\begin{tabular}{ll}
\hline Stakeholder groupings & $\begin{array}{l}\text { Number in the } \\
\text { university council }\end{array}$ \\
\hline The senior executive management & 4 \\
senate representatives & 2 \\
convocation & 2 \\
student representatives & 2 \\
academic employee & 1 \\
service employee & 1 \\
administrative employee & 1 \\
organised business/ private sector & 6 \\
Appointees of the Minister of Education & 5 \\
Donor representation & 2 \\
Resource persons & 3 \\
Provincial representative & 1 \\
Municipal representative & 1 \\
\hline
\end{tabular}

Effective governance in such stakeholder governed university councils is related to how the university council is able to reach consensus with its different stakeholders in spite of their differences. The successful consensus is determined by the university leadership as provided by the university council chairperson at the level of the general assembly of the university council. In addition, the leadership provided by the chairpersons of the different committees of the university councils.

The university council leadership performs the following roles: firstly, ensuring there are sufficient accountability procedures and practices with regard to the effective governance of institutional funds and income, resources to secondly boost stakeholder confidence in institutional values that guide effective institutional governance. The University Council works hand in hand with its university management under the leadership of the university vice chancellor. The university vice-chancellor is key in ensuring that the university council's decisions and directions are followed on key aspects of accountability and stakeholder engagement relations /confidence.

\subsection{The University Council Accountability and Audit Practices}

Auditing is an organizational self-examination process which instils a sense of ownership and agency for relevance. An institutional audit involves a process that institutions undertake for themselves to check that they have procedures in place to assure quality, integrity or standards of provision and outcomes across the institution. The Higher Education Quality Committee (HEQC), tasked with conducting audits of South African higher education institutions, commenced the first cycle of audits in 2004. The HEQC audit system also takes into account the need to adapt some of its criteria according to the mode of delivery in which an institution offers its academic programmes and the CHE has developed specific criteria for distance and open learning institutions. The HEQC (2007) states that Audits are a form of external quality assurance in which institutions' self-assessments against criteria are validated by panels of experts and peers. The university council as its institutional practice to embrace and participate in these activities has put in place the following institutional units: 
i) The roles and responsibilities of the internal audit office

ii) The roles and responsibilities of the finance office

iii) The place and roles of the risk and security office.

\section{i) The roles and responsibilities of the internal audit office}

The internal audit portfolio is located in the vice-chancellor's office and is aimed at institutional compliance and the reviewing of the effectiveness of the institutional systems (University of Venda, 2011). The university council often times expects the vice-chancellor's office to furnish the university council at its sessions with what is going on in the institution concerning particular set targets by the university council that it expects the senior management to have accomplished. As part of its driving initiative at providing institutional effectiveness, this process involves a close working relationship between the vice-chancellor's office and the different institutional portfolios that the office handles. The vice-chancellor's office is expected to be at abreast with every institutional activity that is taking place at the university in order to fully account before the university council at request. These institutional audits test the institution's readiness to respond and how the different sectors of the institution are performing on agree institutional targets.

\section{ii) The roles and responsibilities of the finance office}

The Directorate for finance established by the university council has been working alongside with the university council committee on finance an executive management committee on issues of financial management and risk pertaining to the university (University of Venda, 2011). This has included preparing regular financial reports for senior management, executive management committee of council, council and other external stakeholders.

\section{iii) The place and roles of the risk and security office}

In post-apartheid higher education environments, HEIs are prone to a variety of institutional risks that governing bodies have to address if they are to provide effective university governance. A risk committee was set up at the University of Venda to identify all categories of possible institutional risks that could face the institution considering its location and history. The university council adoption of a risk management strategy with a detailed framework compliance report shows the institutions readiness to respond to institutional instabilities that characterise the former HDIs.

Reviews of the institutional documents in the public domain indicate that the university council has permitted several institutional audits to determine the institutional readiness (University of Venda, 2011). There are different types of audits, for example, financial and quality audits which seek to reassure the state and the general public that their funds are being used efficiently and effectively and that they are receiving educational value in return for their monetary investments. These evaluations often reveal major areas weakness and strengths that demand attention as possible indicators for institutional effectiveness (University of Venda, 2011). The willingness to engage with findings of these evaluations as often as possible shows an institutional best practice of willingness to change through responsiveness.

The HEQC (2007) states that the purpose of the audit is to assess the effectiveness of the systems that institutions have put in place to manage the quality of their core functions, identify areas of strength that should be acknowledged or commented, and areas of weaknesses that need to be addressed with different degrees of urgency. In this sense, audits are both about accountability and development. Audits focus on accountability in that institutions have to demonstrate that they have appropriate systems to take care of the quality of their core functions, that these systems function and have an effect on the quality of academic provision. But audits also focus on development as they seek to identify those areas that need improvement so that institutions can develop the necessary strategies to effect such improvement (University of Venda, 2011).

The role of the empowered institutional stakeholders in the evaluation process is significant. Successful institutional evaluations are when these groups of stakeholders are subsequently involved in the process, in terms of understanding the purpose, aims and outcomes of the processes at their different governance levels (HEQC, 2007). Otherwise, the stakeholder politicisation of the outcomes of the process by these empowered stakeholders would affect how the university governing should respond as a way of bringing about institutional effectiveness. Institutions do not "pass" or "fail" audits and are not rewarded or penalised accordingly (HEQC, 2007). Audits provide institutions with a unique opportunity to acquire self-knowledge. Institutions are required through the audit process to engage critically with their conceptualisation of the three core functions: the effectiveness of their systems for 
quality; their historical trajectories; their position within the higher education system; as well as to assess their strategies and plans for the future (HEQC, 2007).

Table 3. The university staff perception on viable audit process in the university council

\begin{tabular}{llrrrr}
\hline & Frequency & Percent & Valid Percent & Cumulative Percent \\
\hline Valid & 5 & 7.8 & 7.8 & 7.8 \\
& Strongly Disagree & 7 & 10.9 & 10.9 & 18.8 \\
Disagree & 11 & 17.2 & 17.2 & 35.9 \\
Neither Agrees nor Disagrees & 32 & 50.0 & 50.0 & 85.9 \\
Agree & 8 & 12.5 & 12.5 & 98.4 \\
Strongly Agree & 1 & 1.6 & 1.6 & 100.0 \\
No Selection & 64 & 100.0 & 100.0 & \\
Total & & &
\end{tabular}

The results of this study show that of those university staff who took part in this study $62.5 \%$ strongly believe that university council accountability and viable audit practices are contributing sufficiently to effective governance in the university. $18.7 \%$ do not believe that university council accountability and viable audit practices are contributing sufficiently to effective governance in the university. $17.2 \%$ are undecided of their position that university council accountability and viable audit practices are contributing sufficiently to effective governance in the university. However, it's sufficient to say that the majority of the university staff agree that university council accountability and viable audit practices are contributing sufficiently to effective governance in the university.

\subsection{Stakeholder Confidence}

Universities are viewed as ivory towers and institutional stakeholder faith and trust are based on what they expect the university as custodians of knowledge to contribute to their communities. The resurgence of the university fees must fall protests with the calls decolonisation of the university in 2015 are the indication of how far the different institutional stakeholders of the university staff and students had lost confidence in the leadership and governance of the universities. From the results of this study, university staff provide the outlook to this aspect.

Table 4. The university staff perception on confidence in the institutional values that underpin effective governance

\begin{tabular}{|c|c|c|c|c|c|}
\hline & & Frequency & Percent & Valid Percent & Cumulative Percent \\
\hline \multirow[t]{7}{*}{ Valid } & Strongly Disagree & 4 & 6.3 & 6.3 & 6.3 \\
\hline & Disagree & 9 & 14.1 & 14.3 & 20.6 \\
\hline & $\begin{array}{l}\text { Neither Agrees nor } \\
\text { Disagrees }\end{array}$ & 23 & 35.9 & 36.5 & 57.1 \\
\hline & Agree & 17 & 26.6 & 27.0 & 84.1 \\
\hline & Strongly Agree & 9 & 14.1 & 14.3 & 98.4 \\
\hline & No Selection & 1 & 1.6 & 1.6 & 100.0 \\
\hline & Total & 63 & 98.4 & 100.0 & \\
\hline Missing & System & 1 & 1.6 & & \\
\hline Total & & 64 & 100.0 & & \\
\hline
\end{tabular}

The results of this study show that of those university staff who took part in this study $40.7 \%$ strongly believe in the institutional values that underpin institutional governance in the university. $20.4 \%$ do not believe in the institutional values that underpin institutional governance in the university. $35.9 \%$ are undecided of their position about institutional values that underpin institutional governance in the university. However, it's sufficient to say that from these results clearly, the majority of the university staff are supportive of prevailing institutional values that underpin effective governance in the university. 
Table 5. The mean standard deviation of the university staff on issues of university council viable audit processes and confidence in institutional values

\begin{tabular}{|c|c|c|c|c|c|}
\hline & $\mathrm{N}$ & Minimum & Maximum & Mean & Std. Deviation \\
\hline Viable audit process & 64 & 1 & 6 & 3.53 & 1.140 \\
\hline $\begin{array}{l}\text { Confidence in the } \\
\text { institutional values }\end{array}$ & 63 & 1 & 6 & 3.33 & 1.136 \\
\hline Valid N (listwise) & 63 & & & & \\
\hline
\end{tabular}

The mean and standard deviation are used in providing more understanding to the relationship between the two variables in the study.

Table 6. Relationship between the University council viable audit processes and confidence in institutional values

\begin{tabular}{llrr}
\hline & & $\begin{array}{c}\text { Viable Audit } \\
\text { Process }\end{array}$ & $\begin{array}{c}\text { Confidence in the institutional } \\
\text { Values }\end{array}$ \\
\hline Viable Audit Process & Pearson Correlation & 1 & .223 \\
& Sig. (2-tailed) & & .079 \\
& $\mathrm{~N}$ & 64 & 63 \\
Confidence in the & Pearson Correlation & .223 & 1 \\
institutional Values & Sig. (2-tailed) & .079 & 63 \\
& $\mathrm{~N}$ & 63 & \\
& & &
\end{tabular}

The results of this study show that at 0.05 level (2-tail test) there was the positive low linear relationship between accountability practices $(\mathrm{m}=3.53, \mathrm{SD}=1.140)$ and stakeholder confidence in institutional values that underpin effective governance in the university $(\mathrm{m}=3.33, \mathrm{SD}=1.136)$ with $\mathrm{r}=0.223, \mathrm{p} \geq 0.05, \mathrm{n}=64, \mathrm{r} 2=4.973$. This implies that $5 \%$ of variance scores for effective governance can be explained by the relationship accountability practices of the university council and stakeholder confidence in institutional values that underpin effective governance in the university, $95 \%$ of the variance scores for effective governance in this study can be attributed to other factors.

\section{Discussion}

There are probably reasons for this kind of relationships from the data in this study collected through documentarily analysis and interviews; firstly, the little university staff representation in the university councils. In the stakeholder governed university councils, numbers play a critical role in the decision making moments. Members of the university council from interest groups are expected to be politically correct during the decision-making process even though whatever is being decided upon does jeopardise and stresses the university purpose and vision. Secondly, the little understanding of how the university councils operate. The inability to understand how the university councils operate is responsible for the ineffective participation in the university councils. Thirdly, the pollicisation of the university council processes that have made the University council vulnerable to negative stakeholder politics that challenge effective governance practice. However, in spite of these aspects that have proved critical for the low relationship between the two variables, the following issues are fundamental in the reconceptualization of this relationship to improve effective governance in the strong stakeholder governed university councils:

\subsection{Institutional Reputation}

Stakeholder accountability is about establishing key branding and building stakeholder reputation. Institutional stakeholders need to feel that the university governing leadership is acting in their best interests in whatever the university governing councils are presiding over (CHE, 2004). The challenge with the postcolonial African universities is that they are trying to cater for the interests of what they were not prepared for as a result they are enveloped in a struggle for stakeholder legitimacy with their key stakeholders in these universities (Mazui, 2013; Nkrumah, 1961). As a result, there is a strong disconnect between the universities and what the stakeholders are expecting from the universities (Sawyerr, 2005). The universities are not dancing to the drums and songs of their stakeholders within the university communities. That is why there is a lot of stakeholder alienation and distrust. They don't see and perceive these universities as belonging to them or working for they stakeholder interest (Yesfu, 1973). 
This sense of stakeholder alienation at different levels of governance relationships has been the key triggers of the increased calls for the decolonisation of the university (Magkoba, 2005; Mbembe, 2015).

As such good governance is when the university governing bodies are able to create governance spaces to make some hard choices to becoming accountable. In this process, to the prevailing concerns, inspirations and needs of its current stakeholders where the universities are located as working initiatives without jeopardising the vision of the university. These generated working responses as stakeholder accountability barometers on key issues of concern can be used to build the institutional reputation and brand within a particular location.

\subsection{Responsiveness}

Stakeholder accountability is about strategic responsiveness within particular institutional environments. The greatest tragedy of the postcolonial African universities has been stakeholder presumption. The propagated assumption that the university will automatically cater for the citizens of the communities they are located (Desai, 2001; Letsekka, 2013; Mohamedbhai, 2011; Sawyerr, 2005). The history of the post-colonial African university has shown no remorse about this through its end products, ambitions and activities. This resurgence of the calls for the decolonisation of the university as a result of the unabated insensitivity and aloofness of the university governing bodies within the particular stakeholder communities where the universities are located to intelligently decode and interpret the local gospels [material conditions] and the state mind of their stakeholder on fundamental issues of expectations over time. Until that time, over deliberately the university councils are able to come to a position and spaces where they are able to create structures, process and practises that take down the elephants in the room on fundamental issues of social justice, equity and responsiveness, effective governance is but a dream let alone being an illusion.

\subsection{Sustainability}

Stakeholder accountability is about protracted sustainability. A major casualty and misfortune of the postcolonial African university have been the tragedy of embarking on a journey and failing to complete it. Beginning to build a house and failing to complete it. The tap root of institutional colonialism and its deceptive fruits of paradigms and knowledge are so deeply entrenched in the psychic (Lebakeng et al, 2006) of the current university governance system that one strike cannot take it down. It took a deliberate time, efforts and diverse forms of resources to plant coloniality within institutions of higher learning and societies (Ngugi, 1986; Fricker, 2009). Consequently, their removal will take a protracted conscious focused engagement (Mignolo, 2009) at different levels of institutional governance under the jurisdiction of the university councils. Oftentimes, as the university student fees must fall protests of 2015 and Rhodes must fall protests have shown and exposed how the university governing councils do not know how to fight this kind of battle. University governing councils had become accomplices, had found being 'dining with the enemy' (Free higher education fees must fall movement, 2017) through adoption and perpetuation of governance practises and systems that encouraged stakeholder alienation and epistemic violence at different institutional levels.

\subsection{Skill Stakeholder Participatory Due Diligence}

Lastly, stakeholder accountability is about skill based participatory due diligence. The university governing councils are expected to set up due process and practises that encourage participation of the different stakeholders in the locatives where the universities are founded (CHE, 2004a). Strategic stakeholder participation builds trust, faith, belonging and ownership key ideological ingredients for institutional de-colonial branding. The failure to quickly incorporate these ideas as projected through the state policy of cooperative governance for institutional transformation for the university councils is basically what we are witnessing today as calls for the urgent decolonisation of the university (CHE, 2005).

One of the key fundamental phobias of the postcolonial African university is that it is too afraid of its key institutional stakeholders. They are several reasons why current post-colonial African university is afraid of its institutional stakeholders it is expected to serve. Firstly, they were not really founded to serve the local citizenry (Ndlovu-Gatsheni, 2014). Secondly, as result they have not fundamentally developed the conditions, and energies to allow the locally generated capacities as guiding knowledges' to learn from its mistakes, to flourish, grow and develop in terms of locally progressive habitus processes, procedures and practises (Wilson-Tuagoe, 2007; Nyamnjoh, 2011; Ndudere, 2003). As a result, the call for decolonization is the tall call to them a dream too far. It's call by the fed up stakeholders to be given chance, opportunities to contribute to this intellectual project to which current institutions 'caught- in -the- mix' have little or no answers yet. 
The deliberate original project and program of coloniality were to lock out its subjects through diverse subtle forms of epistemic violence at different levels over time (Packerham, 1992; Augusto, 2007). Unfortunately, these practices still persist in different forms. University governing bodies are suspicious of its none academic and academic university staff. It is not surprising that being a university staff and student within such institutional contexts one has to learn how to live with certain amounts of institutional uncertainty, distrust, anxiety and alienation as part of the academic journey of developing one's persona. This key features of stakeholder accountability need to be generated around reimagination of institutional strategies in the communities' the universities are founded and come out of governances spaces and positions they inherited as extensions, and instrumentalities of coloniality in their journey to institutional de-colonialization.

\section{Conclusions and Implications for Effective Governance}

In conclusion, this paper has responded to the recurrent debates in higher education has about the role of stakeholder governed university councils in the post-1994 South African higher education in the transformation and decolonisation of higher education. Internationally literature tells informs us how university governing bodies have to grapple with competing challenges of effectiveness, efficiency, participation and responsiveness to provide good governance. In response to these competing debates what really remains are what steps the university councils are doing as part of their best governance practises as institutional positionality. Catching up with these issues, this paper has examined the relationship between accountability practices of the university council as the major decision maker in the university and the resulting stakeholder confidence. The results of this study show that there was the positive low linear relationship between accounting practices and stakeholder confidence in institutional values that underpin effective governance in the university. The low linear relationship is an indicator of the kinds of governance challenges confronting the strong stakeholder governed university councils as they try to bring about university transformation.

Thus, as much as there is no size-fits- all model of university governance that can apply for all complex university contexts. This has the following implications for effective governance by university governing councils across comprehensive universities: The university governing councils need to create governance spaces to make some hard choices to become accountable to the prevailing concerns where the universities are located as working solutions without jeopardising the vision of the university. Secondly, it requires a protracted conscious focused stakeholder engagement at different levels of institutional governance under the jurisdiction of the university councils. Lastly, it calls for strategic stakeholder participation with the potentiality and positionality to build trust, faith, belonging and ownership key ideological ingredients for institutional de-colonial branding. That is why in these times, it is urgent to reimagine the kinds of universities that are needed in the postcolonial societies in terms of relevance, ideology, sustainability and responsiveness. Subsequently, this creates need for more studies to strengthen the relationship between the two factors under different institutional contexts. As the relationship between these practises is fundamental for effective governance.

\section{References}

Aldeman, C., \& Kevin, C. (2009). Ready to Assemble: Grading State Higher Education Accountability Systems. Washington, DC: Education Sector.

Asmal, K. (2002). Statement on the transformation and reconstruction of higher education systems. Pretoria: Ministry of Education.

Augusto, G. (2007). Transforming Knowledge, Changing Knowledge Relations, and Epistemic Openness in the University in Africa. Social Dynamics, 33(1), 199-205. https://doi.org/10.1080/02533950708628749

Bailey, K. (1994). Methods of Social Research (4th ed.). New York: The Free Press.

Baldridge, J. V., Curtis, D., V., George P, E., \& Gary, L. R. (1983). Alternative models of governance in higher education. In R. Birnbaum (Ed.), ASHE reader in organization and governance in higher education (p. 437). Lexington, Mass.: Ginn Custom Pub.

Baldridge, J.V., \& Riley, L.G. (1977). Governing academic organization. Berkeley, CA: McCutchan Publishing Corporation.

Blase, J. (1998). The micro politics of education change. In A. Hargreaves, A. Lieberman, M. Fullan \& D. Hopkins (Eds.), International handbook of educational change (pp. 544-557). London: Kluwer Academic Publishers.

Bourdieu, P. (1996). The State Nobility: Elite schools in the field of power. Cambridge: Polity Press. 
Burke, J. C., \& Henrik, M. (2003). "Real" Accountability or Accountability "Lite": Seventh Annual Survey 2003. The Nelson A. Rockefeller Institute of Government, State University of New York.

Casper, C. A., \& Myron S., H. (2001). Developing Performance-Oriented Models for University Resource Allocation. Research in Higher Education, 42(3), 353-376. https://doi.org/10.1023/A:1018826107394

Cesaire, A. (1972). Discourse on Colonialism. New York: Monthly Review.

Cloete, N., \& Maassen, P. (2002). 'The limits of policy'. In Cloete, Fehnel, Maassen, Moja, Perold \& Gibbon (Eds.), Transformation in higher education: global pressures and local realities in South Africa. Cape Town: Juta.

Corbetta, P. (2003). Social research theory, methods and techniques. London: SAGE Publications. https://doi.org/10.4135/9781849209922

Council of Higher Education. (2000). Towards a New Higher Education Landscape. In CHE (Ed.), Report to the Minister of Education. Pretoria: Council on Higher Education.

Council of Higher Education. (2004). South African higher education in the first decade of democracy (pp. 175-185). Pretoria: CHE. Concept document. Commissioned Report by Trish Gibbon. Pretoria.

Council of Higher Education. (2007). Institutional Audit Manual Pretoria Higher Education Quality Committee.

Council of Higher Education. (2011). Audit Report on the University of Venda. Pretoria: the Higher Education Quality Committee.

Creswell, J. W., Clark, V. L. P., Gutmann, M. L., \& Hanson, W. E. (2003). Advanced mixed methods research designs. In A. Tashakkori \& C. Teddie (Eds.), Handbook of mixed methods Research. In social and behaviour research (pp. 209-240). London: Sage.

Cross, M., \& Naidoo, D. (2011). Peer and the dilemmas of quality control in programme accreditation in South African higher education: Challenges and possibilities. Higher Education Policy, International Association of Universities, 24, 517-534. https://doi.org/10.1057/hep.2011.13

Department of Education, (2000). The investigation into the affairs of the University of the North by the Independent Assessor [Professor T. Nhlapo] appointed by the Minister of Education in terms of Chapter 6 of the Higher Education Act, No. 101 of 1997. Government Gazette, 21654, 10 October 2000. Pretoria: Government Printers.

Department of Education. (1997). Education White Paper 3: A programme for higher education transformation. Government Gazette, 386 (18207). Pretoria: Government Printers.

Department of Education. (1998). An investigation conducted at the University of Transkei.

Department of Education. (1999). An investigation conducted at the University of Fort Hare, Report to the Minister of Education, the Honourable S. M. E. Bengu by Emeritus Professor S. J. Saunders. Government Gazette, 19842, 12 March 1999. Pretoria: Government Printers.

Department of Education. (2011). An investigation conducted at the University of Kwa-Zulu Natal. The outcomes of the independent assessor's report on the Vaal University of Technology by Prof De Beer appointed by the Minister of Education in terms of Chapter 6 of the Higher Education Act, No. 101 of 1997. Pretoria: DoE.

Dussel, D. A. E. (1985). Philosophy of Liberation. New York. Orbis Books.

Eckel, P. D. (2003). Changing course: Making the hard decisions to eliminate academic programs. Westport CT: Greenwood/Praeger.

Fielden, J. (2008). Global Trends in University Governance. Education Working Paper Series No. 9. Washington, DC: World Bank.

Foucault, M. (1991). Governmentality. In G. Burchell, C. Gordon, \& P. Miller (Eds.), The Foucault effect: studies in governmentality (pp.87-105). Hemel Hempstead (UK): Harvester Wheatsheaf.

Freire, P. (1993). Pedagogy of the Oppressed. London Penguin Books.

Fricker, M. (2009). Epistemic Injustice: Power and the ethics of knowing. Oxford: Oxford University Press.

George, D., \& Mallery, P. (2003). SPSS for Windows step by step: A simple guide and reference. 11.0 update (4th ed.). Boston Allyn \& Bacon.

Groves, R. M., Fowler, F. J., Couper, M. P., Lepkowski, J. M., Singer, E., \& Tourangeau, R. (2004). Survey methodology. Hoboken, NJ: John Wiley \& Sons. 
Habib, A. (2001). The institutional crisis of the University of Transkei. Politikon, 28(2), 157-179. https://doi.org/10.1080/02589340120091637

Hall, M., Symes, A., \& Luescher, T. M. (2002). Governance in South African higher education. Research report prepared for the Council on Higher Education.

Higher Education Act, a statute of a university of Venda Government gazetted Act no. 101 of 1997 Stat. (Department of Higher Education and Training 1997).

Kezar, A. J., \& Eckel, P. D. (2004). Meeting today's governance challenges: a synthesis of the literature and examination of a future agenda for a scholarship. Journal of Higher Education, 75(4), 371-399. https://doi.org/10.1080/00221546.2004.11772264

Lebakeng, J. T., Phalane, M. M., \& Dalindjebo, N. (2006). Epistemicide, Institutional Cultures and the Imperative for the Africanisation of Universities in South Africa. Alternation, 13(1), 70-87.

Letsekha, T. (2013). Revisiting the debate on the Africanisation of higher education: An appeal for a conceptual shift. The Independent Journal of Teaching and Learning, 8, 5-18.

Liefner, I. (2003). Funding, Resource Allocation, and Performance in Higher Education Systems. Higher Education, 46(4), 469-489. https://doi.org/10.1023/A:1027381906977

Magkoba, M. W. (2005). The African University: Meaning, penalties and responsibilities. In D. Chetty (Ed.), Towards African scholarship (pp. 11-19). Durban: Public Affairs \& Corporate Communications, UKZN.

Magubane, B. (2007). Race and the Construction of the Dispensable Other. Unisa Press.

Maldonado, T., N. (2007). On the Coloniality of Being: Contributions to the Development of a Concept. Cultural Studies, 21(23), 240-270. https://doi.org/10.1080/09502380601162548

Marshall, J. (2009). FRANCE: Universities begin to move to autonomy. University World News, 12 January 2009.

Mazrui, A.A. (2003). Towards re-Africanizing African universities: Who killed intellectualism in the post-colonial era? Alternatives. Turkish Journal of International Relations, 2(3/4), 135-163.

Mbembe, A. (2001). On the Postcolony. London. Berkeley. Los Angeles: University of California Press.

Mbembe, A. (2015). Decolonizing Knowledge and the Question of the Archive. Retrieved from http://wiser.wits.ac.za/system/files/Achille\%20Mbembe\%20-\%20Decolonizing\%20Knowledge\%20and\%20the \%20Question\%20of\%20the\%20Archive.pdf

Mignolo, W. D. (2008). Preamble: The historical foundation of modernity/coloniality and the emergence of colonial thinking. A companion to Latin American literature and culture, p. 1252. https://doi.org/10.1002/9780470696446.cha

Mignolo, W. D. (2009). Epistemic disobedience, independent thought and colonial freedom. Theory, Culture \& Society, 26(7/8), 159. https://doi.org/10.1177/0263276409349275

Mohamedbhai, G. (2011). Higher education in Africa: Facing the challenges of the 21st century. International Higher Education, 63(Spring), 20-21.

Moja, T., \& Hayward, F. (2000). Higher education policy development in contemporary South Africa Higher Education Policy, 13, 335-359. https://doi.org/10.1016/S0952-8733(00)00017-9

Nabudere, D. W. (2003). Towards the Establishment of a Pan-African University: A Strategic Concept Paper. African Journal of Political Science, 8(1), 1-29.

Nabudere, D. W. (2011). Africology, Philosophy and Wholeness: An Epistemology. Pretoria. Africa Institute of Africa.

Ndlovu-Gatsheni, S. J. (2014). Global coloniality and the challenges of creating African futures. Strategic Review for Southern Africa, 36(2), 181-202.

Neave, G., \& Frans A. V. V. (1994). Government and Higher Education Relationships across Three Continents. Pergamon Press, Oxford.

Ngugi, J. (1986). Decolonizing the Mind: The Politics of Language in African Literature. London: James Currey.

Nkrumah, K. (1961). Flower of learning (1). Address at his installation as the first chancellor of the University of Ghana. Retrieved from http://nkrumahinfobank.org/article.php?id=470\&c=46 
Nyamnjoh, F., B. (2011). Relevant Education for African Development: Some Epistemological Considerations. In L. Keita (Ed.), Philosophy and African Development: Theory and Practice (pp. 139-154). Dakar: CODESRIA.

Ogle, G. Cristin, T., \& Novak, R. (2008). Public Higher Education Governing and Coordinating Boards: Composition, Characteristics, and Structure. Washington, DC: Association of Governing Boards of Universities and Colleges.

O'Leary, Z. (2005). Researching real-world problems: a guide to methods of inquiry. London Sage Publications.

Packenham, T. (1992). The Scramble for Africa. Abacus.

Payne, G., \& Payne, J. (2004). Key Concepts in Social Research. London: Sage Publications. https://doi.org/10.4135/9781849209397

Punch, K. (2009). Introduction to research methods in education. Los Angeles: Sage.

Report by Advocate T. L. Skweyiya S.C. (Appointed as Independent Assessor in terms of Sections 44 and 45 of the Higher Education Act, No. 101 of 1997). Government Gazette, 19501, 20 November 1998. Pretoria: Government Printers.

Rousseau, J. (2011). Discourse on the Origin and Foundations of Inequality among Men. New York: Bedford/St. Martin's.

Said, E. (1983). "Travelling Theory" in the World, the Text and the Critic. London. Faber and Faber.

Sawyerr, A. (2005). Challenges facing the African University: Selected issues. African Studies Review, 47(1), 1-59. https://doi.org/10.1017/S0002020600026986

Sporn, B. (2002). World Class Reform of Universities in Austria. International Higher Education, 29.

Steyn, M., \& van Zyl, M. (2001). Like that Statue at Jammie Stairs...: Some student perceptions and experiences of institutional culture at the University of Cape Town in 1999. Research Report, Institute for Intercultural and Diversity Studies at UCT. Cape Town: University of Cape Town.

Wilson-Tagoe, N. (2007). The University in Africa: A Perspective on Transformation. Social Dynamics, 33(1), 238-241. https://doi.org/10.1080/02533950708628756

Yesufu, T., M. (Ed.) (1973). Creating the African University: Emerging issues of the 1970s. Ibadan, Nigeria: Oxford University Press.

Yin, R. K. (2003). Case study research: Design and methods (3rd ed.). Newbury Park: Sage. 